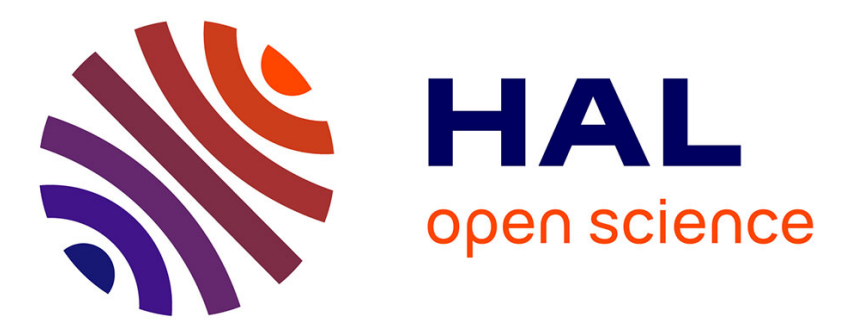

\title{
Comparison of cyanobacteria monitoring methods in a tropical reservoir by in vivo and in situ spectrofluorometry
}

Talita Silva, Alessandra Giani, Cleber Figueredo, Priscila Viana, Bruno J. Lemaire, Bruno Tassin, Nilo Nascimento, Viet Tran Khac, Brigitte

Vinçon-Leite

\section{To cite this version:}

Talita Silva, Alessandra Giani, Cleber Figueredo, Priscila Viana, Bruno J. Lemaire, et al.. Comparison of cyanobacteria monitoring methods in a tropical reservoir by in vivo and in situ spectrofluorometry. Ecological Engineering, 2016, 97, pp.79-87. 10.1016/j.ecoleng.2016.06.037 . hal-01770340

\section{HAL Id: hal-01770340 \\ https://hal-enpc.archives-ouvertes.fr/hal-01770340}

Submitted on 21 May 2018

HAL is a multi-disciplinary open access archive for the deposit and dissemination of scientific research documents, whether they are published or not. The documents may come from teaching and research institutions in France or abroad, or from public or private research centers.
L'archive ouverte pluridisciplinaire HAL, est destinée au dépôt et à la diffusion de documents scientifiques de niveau recherche, publiés ou non, émanant des établissements d'enseignement et de recherche français ou étrangers, des laboratoires publics ou privés. 


\section{Comparison of cyanobacteria monitoring methods in a tropical reservoir by in vivo and in situ spectrofluorometry}

TalitaSilva $^{\text {ab }}$ AlessandraGiani $^{\mathrm{c}}$ CleberFigueredo $^{\mathrm{c}}$ PriscilaViana $^{\mathrm{c}}$ Viet TranKhac $^{\mathrm{ab}}$ Bruno J.Lemaire $^{\mathrm{b}}$ BrunoTassin $^{\mathrm{b}}$ NiloNascimento ${ }^{a}$ BrigitteVinçon-Leite ${ }^{b}$

Department of Hydraulic and Water Resources, Universidade Federal de Minas Gerais, 6627 av. Antônio Carlos, CEP 31270-901 Belo Horizonte, Minas Gerais, Brazil

Université Paris-Est, LEESU, Ecole des Ponts Paris Tech, UPEC, AgroParisTech, F-77455, Marne-la-Vallée, France

Department of Botany, Institute of Biological Sciences, Universidade Federal de Minas Gerais, 6627 av. Antônio Carlos, CEP 31270-901 Belo Horizonte, Minas Gerais, Brazil

\section{Introduction}

In order to improve lake water quality and to prevent loss of services provided by aquatic

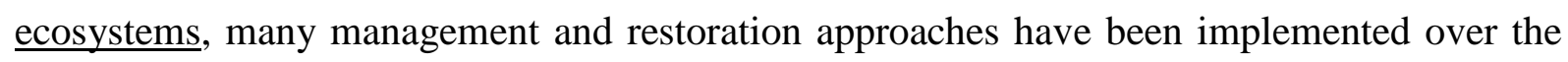
past years (Søndergaard et al., 2007). The choice of the most appropriate lake restoration approach and the measure of its effectiveness rely on monitoring programs, which may provide key information about the aquatic ecosystem functioning. Among parameters commonly used to assess water quality of lakes, the phytoplankton biomass and diversity is of great ecological significance because this community comprises the major portion of primary producers in aquatic ecosystems. Moreover, phytoplankton microorganisms present high reproduction rates and respond rapidly to environmental changes (Richardson, 2008), which is fundamental when studying the changes occurring due to a management strategy or due to environmental impacts. Phytoplankton diversity seems to be similar in tropical and temperate lakes (Lewis, 1996), but lake thermal behavior, nutrient cycling and phytoplankton dynamics may vary across the latitude (Lewis, 2000; von Sperling, 1997). Furthermore, tropical freshwaters are more prone to severe eutrophicationproblems due to insufficient sanitation (von Sperling, 1997) and specific meteorological conditions, such as droughts (Bouvy et al., 2003, 1999). Monitoring phytoplankton composition and biomass is highly relevant to improve management of tropical water bodies.

Although methods for determining algal biomass are widely employed since ecological studies on freshwaters started, controversy remains about which techniques are the most appropriate. Phytoplankton quantification by microscopy and biovolume determination are frequently assumed to correspond to the "real" algal biomass, nevertheless it is fairly known that this method is time-consuming and requires experimented staff knowledge (Paxinos and Mitchell, 2000). Spectrometry determination of chlorophyll $a(\operatorname{chl} a)$ has been widely used as a 
phytoplankton biomass proxy, because it is simpler and faster than microscopy analysis and provides acceptable results (Jeffrey et al., 1997).

Notwithstanding, the delay between sampling and analysis in phytoplankton counting and chla quantification methods limits the number of samples that can be collected and stored, and consequently the spatial and temporal monitoring frequency (Dworak et al., 2005). Portable spectrofluorometer were developed to overcome this difficulty: they are easy to handle and provide a swift and suitable temporal and spatial in situ quantification of phytoplankton biomass (MacIntyre et al., 2010). The algal fluorometric differentiation relies on the in vivo autofluorescence of chla and accessory pigments. The proportions between accessory pigments and chl $a$ result in an excitation spectrum, later called "fingerprint", specific for a taxonomical phytoplankton class (Dau, 1998; Huot and Babin, 2010). The ability of such a probe, the FluoroProbe (FP-BBE FluoroProbe, Moldaenke, Germany), to estimate phytoplankton biomass and taxonomic composition has been demonstrated in different water bodies, mainly in temperate climate regions (Catherine et al., 2012; Gregor et al., 2005; Gregor and Maršálek, 2004; Rolland et al., 2010). This probe has been used to study the temporal variability in marine phytoplankton photosynthetic activity (Houliez et al., 2015), the impact of the resuspension of contaminated sediment on phytoplankton (Lafabrie et al., 2013), the influence of microscale turbulence on coastal phytoplankton (Machado et al., 2014), the relationships between toxin and cyanobacteria concentrations in lakes and reservoirs (Salmaso et al., 2014). FP also provided high-resolution data for three-dimensional hydrodynamic and ecological lake modelling (Carraro et al., 2012; Marti et al., 2011).

Despite all its advantages, researches with the submersible spectrofluorometric profiler have also reported some concerns that are not yet clarified and the interpretation of the data deserves some caution. Although total chla given by FP and laboratory spectrophotometry are generally correlated, FP values are frequently underestimated and different degrees of underestimation were observed (see Catherine et al., 2012; Gregor and Maršálek, 2004; Gregor et al., 2005; Leboulanger et al., 2002). Another controversial issue is the upper measuring limit of the probe. According to the manufacturer, the range of reliable measurements is between 0.020 and 200 $\mu \mathrm{g}$ chla $\mathrm{L}^{-1}$. However, Gregor and Maršálek (2004) found a non-linear response of the FP above $50 \mu \mathrm{g} \mathrm{chl} a \mathrm{~L}^{-1}$ in temperate reservoirs with cyanobacteria dominance. Nevertheless, for Catherine et al. (2012) who sampled 50 temperate lakes of differents trophic levels $(0.8-265 \mu \mathrm{g}$ chl $a \mathrm{~L}^{-1}$, dominated by different phytoplankton species, including colonial cyanobacteria, the FP response remained linear.

In this study, we aimed to verify whether the FP could correctly quantify the phytoplankton biomass and its taxonomic composition in a hypereutrophic tropical reservoir. To assess the FP performance in Lake Pampulha we carried out a cross-comparison between FP and laboratory spectrophotometric measurements, as well as with total algal biovolume and taxonomic group biovolume. We also performed laboratory experiments to determine the range of linear response 
of the FP in our study site. We determined in the laboratory the excitation spectrum of the main cyanobacteria species found in the reservoir and compared an average experimental spectrum to the default fingerprint for cyanobacteria provided by the probe manufacturer.

\section{Material and methods}

\subsection{Study site}

Lake Pampulha (Fig. 1) is a small, artificial, hypereutrophic water body located in an urban

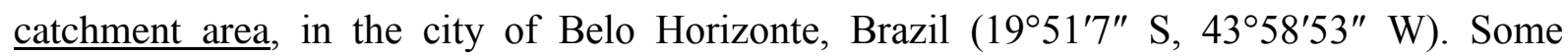
characteristics of the reservoir and its water quality are listed in Table 1.

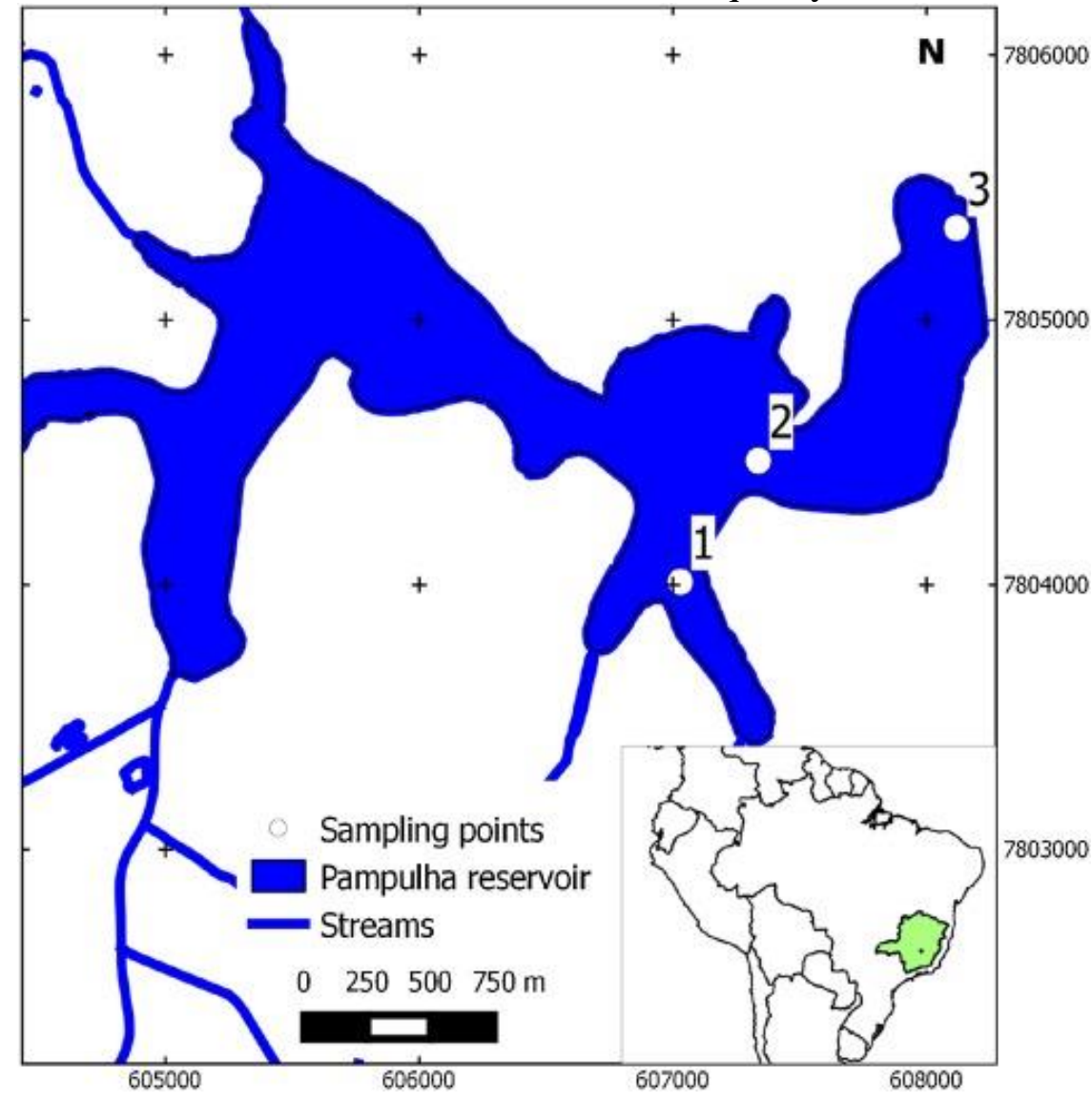

Fig. 1. Lake Pampulha (Brazil) location and sampling sites.

Table 1. Lake Pampulha characteristics and main water quality parameters. Characteristics from Resck et al. (2007). Water quality data: minimum — maximum (mean \pm standard deviation) values obtained from January 2012 to December 2013 at the central point 2, at $0.5 \mathrm{~m}$ depth. Chla measured by spectrophotometry.

\section{Characteristics}

Altitude (m) 


\section{Characteristics}

Maximal depth (m)

Surface (ha)

Volume $\left(\mathrm{m}^{3}\right)$

Water quality parameters

Water temperature $\left({ }^{\circ} \mathrm{C}\right)$

Secchi disc (m)

$\mathrm{P}^{-} \mathrm{PO}_{4}\left(\mu \mathrm{g} \mathrm{L}^{-1}\right)$

Total P $\left(\mu \mathrm{g} \mathrm{L}^{-1}\right)$

$\mathrm{N}-\mathrm{NO}_{3}\left(\mu \mathrm{g} \mathrm{L}^{-1}\right)$

$\mathrm{N}-\mathrm{NH}_{4}\left(\mathrm{mg} \mathrm{L}^{-1}\right)$

Chla $\left(\mu \mathrm{g} \mathrm{L}^{-1}\right)$
16.2

197

$9.9 \times 10^{6}$

$19-28(23)$

$0.1-0.9(0.36 \pm 0.14)$

$2-25(6 \pm 6)$

70-769 (291 \pm 162)

$<30-263(37 \pm 71)$

8-11 (4 \pm 3$)$

$33-570(210 \pm 138)$

\subsection{Sampling}

From October to November 2011 and from August to November 2012, subsurface discrete samples were collected with a Van Dorn sampler from three different points in Lake Pampulha (see Fig. 1), almost twice a week during the first period and fortnightly during the second one, with a total of 37 samples.

Samples were placed in polyethylene bottles and transported in Styrofoam cooled boxes, protected from light and heat. In the laboratory, samples were split for chla and phytoplankton counting.

\subsection{FluoroProbe measurements}

At the same sampling dates, in situ vertical profiles of chla concentration were obtained with the FP using the default fingerprints. The FP is a spectrofluorometer equipped with six lightemitting diodes at $370 \mathrm{~nm}, 470 \mathrm{~nm}, 525 \mathrm{~nm}, 570 \mathrm{~nm}, 590 \mathrm{~nm}$ and $610 \mathrm{~nm}$. It selectively excites accessory pigments, measures the emitted fluorescence and compares it to reference fluorescence excitation spectra called "fingerprints", which by default correspond to four algal groups: i) Chlorophyta; ii) Cyanobacteria; iii) Bacillariophyta, Chrysophyta and Dinophyta; and iv) Cryptophyta. The FP also quantifies coloured dissolved organic matter (CDOM) that also has fluorescent properties. For a detailed description of the FP, see Beutler et al. (2002). Even if taxonomic analysis showed very low or no biomass of Cryptophyta in Lake Pampulha, FP profiles indicated that they accounted for about $20 \%$ of the phytoplankton. Catherine et al. (2012) and Gregor et al. (2005) argued that in case of high cyanobacteria dominance, FP could incorrectly assign cyanobacteria to the "Cryptophyta" group because of the presence of phycoerythrin in both cryptophytes and cyanobacteria cells. Even if no phycoerythrincontaining cyanobacteria were observed, we disabled the Cryptophyta class in the FP software 
to avoid incorrectly assignment of some cyanobacteria. Disabling the Cryptophyta algorithm did not hinder other measurements and allowed us to obtain more reliable results.

\subsection{Laboratory analysis}

\subsubsection{Spectrophotometric chlorophyll-a determination}

Chl $a$ analysis was performed following Nusch (1980). For each sample, a volume of 100-200 $\mathrm{mL}$ of raw water was filtered through a $47 \mathrm{~mm}$ Whatman $\mathrm{GF} / \mathrm{C}$ glass fibre filter, which was frozen at $-20{ }^{\circ} \mathrm{C}$ until analysis. Chl $a$ was extracted in $90 \%$ ethanol at $80{ }^{\circ} \mathrm{C}$ for $5 \mathrm{~min}$ followed by $10 \mathrm{~min}$ of centrifugationto produce a supernatant with minimal turbidity. The absorbance was recorded at 665 and $750 \mathrm{~nm}$ wavelengths in a spectrophotometer (Perkin Elmer Lambda 25, USA), before and after acidification with $0.1 \mathrm{~N} \mathrm{HCl}$.

\subsubsection{Phytoplankton counting and biovolume estimation}

Phytoplankton counting and biovolume estimation were performed in three samples per week (one for each sampling point in the lake) in 2011 and for all samples in 2012. In total, microscopy analyses were performed for 24 of the 37 samples. Samples for phytoplankton identification and counting were preserved with lugol acetic solution and stored at ambient temperature, protected from light. An inverted Zeiss Winkel microscope and $10 \mathrm{~mL}$ chambers were used for cell counting, performed according to the Utermöhl technique (Utermöhl, 1958). Cells were counted until 100 individuals of the dominant species were enumerated. When one species was highly dominant and this number was reached in less than 15 fields, counts went on until the enumeration of 400 individuals of the dominant species, aiming at maintaining the same volume of counted sample. The biovolume of each species was obtained by stereometric calculations according to $\underline{\operatorname{Rott}(1981)}$.

\subsubsection{Determination of the upper limit of the linear response of the FP}

In order to determine the FP upper concentration limit in Lake Pampulha, $10 \mathrm{~L}$ samples were collected at $0.5 \mathrm{~m}$ depth from a central point in the reservoir on August 23rd, 2012 and September 6th, 2012. These samples were diluted with filtered water in order to obtain subsamples of different concentrations.

A $150 \mathrm{~mm}$ diameter polyvinylchloride (PVC) cylinder was filled with the sub-samples, successively from the least to the most concentrated and FP reading (with default fingerprint) was carried out after manual sample homogenization. FP chl $a$ concentration was obtained by averaging measurements recorded during the first three minutes. From these sub-samples, between 100 and $200 \mathrm{~mL}$ were filtered for chla determination by spectrophotometry.

2.4.4. Determination of a mean cyanobacteria fingerprint in Lake Pampulha 
Fingerprints were determined for the dominant cyanobacteria species in Lake Pampulha and compared with the default cyanobacteria fingerprint provided by the probe manufacturer. We focused on cyanobacteria because they were the dominant phytoplankton group in Lake Pampulha during most of the period of study (Fig. 2a). Fingerprints were determined both on single-species cultures and on reservoir samples and averaged to an experimental fingerprint in order to replace the default cyanobacteria fingerprint of the FP.

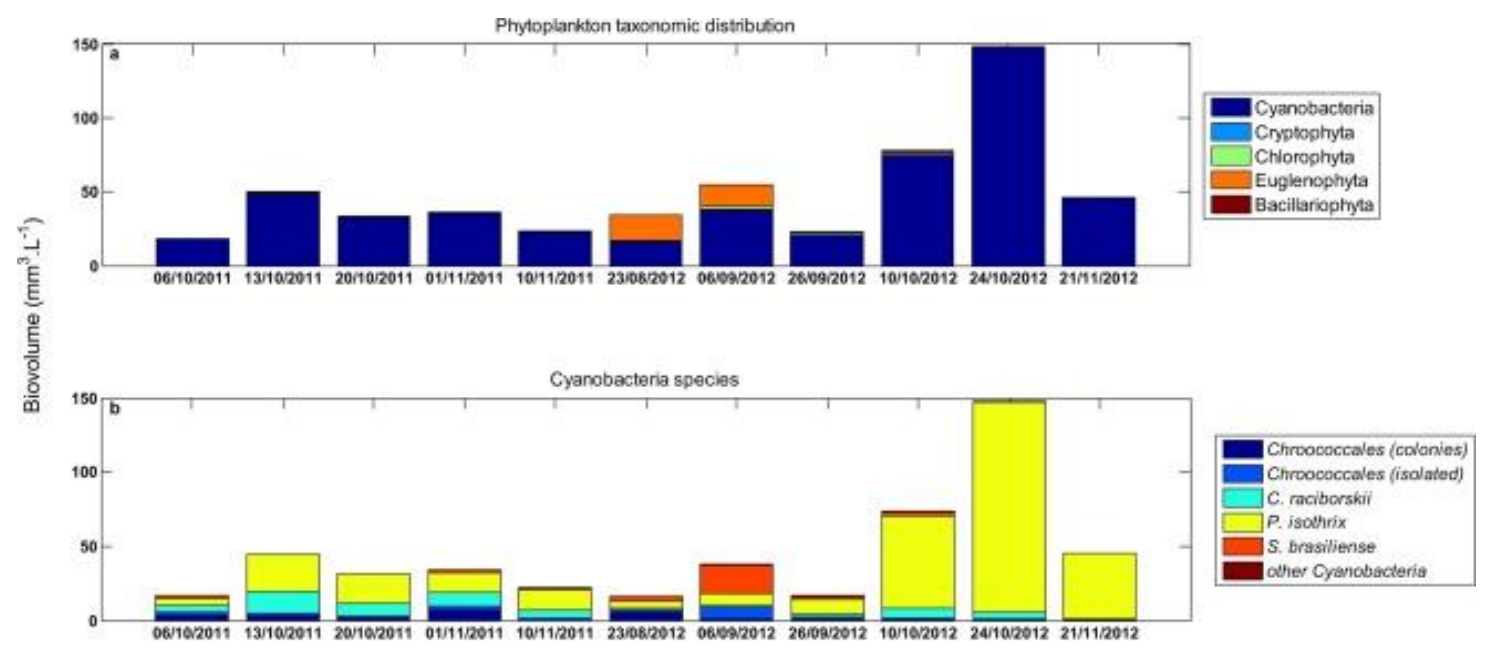

Fig. 2. Biovolume and taxonomic composition in Lake Pampulha at the sampling point 2 (a) total phytoplankton and (b) cyanobacteria.

\subsection{Fingerprints from laboratory cultures}

We used cultures of single-species strains of Microcystis viridis, Cylindrospermosis raciborskii and Arthrospira sp., isolated from Lake Pampulha and belonging to the collection of the Laboratory of Phycology of the Universidade Federal de Minas Gerais, Brazil. It was not possible to use a culture of Planktothrix isothrix because under laboratory conditions, contrary to in situ conditions, this species grows forming tangled filaments. They did not distribute homogenously and impaired measurements with the FP. A second strain of C. raciborskii obtained in Lagoa Santa (MG, Brazil) was also used. Cultures were grown in $250 \mathrm{~mL}$ Erlenmeyer's flasks, in WC medium, at $20{ }^{\circ} \mathrm{C}$, under white light (intensity $=50 \mu \mathrm{E} \mathrm{m} \mathrm{s}^{-1}$ ) and day/night cycles of $12 / 12 \mathrm{~h}$.

After 15 days, samples were collected from the cultures of the four strains. The measurements were performed with the FP benchtop workstation (FluoroProbe Workstation 25), which has a 25-mL cuvette with a magnetic stirrer. Samples were diluted to obtain 4 sub-samples of 100 $\mathrm{mL}$ for each strain, covering the range of chla concentration usually found in Lake Pampulha during the monitored period. FP measurements were performed on each sub-sample. Then, each sub-sample was filtered for duplicate spectrophotometry analyses. 
On each sample, the fluorescence measured by the FP, at each excitation wavelength of the FP, was divided by chla concentration measured by spectrophotometry. This set of relative fluorescence values forms the excitation spectrum, commonly called "fingerprint" (Leboulanger et al., 2002). For each strain, 8 fingerprints were obtained by duplicate chla analysis on four diluted samples. They were averaged to a mean fingerprint with standard deviation at each wavelength.

\subsubsection{Fingerprints from field samples}

In addition to the fingerprints obtained in the laboratory, FP measurements carried out in situ on October 24th and November 21st 2012 were used to determine the fingerprint of $P$. isothrix. This was possible because $P$. isothrixbiomass accounted for more than $96 \%$ of the total phytoplankton biovolume on these dates, according to the taxonomic analysis (Fig. 2b).

2.5.2. Replacement of default cyanobacteria fingerprint by mean experimental fingerprint

A mean experimental cyanobacteria fingerprint in Lake Pampulha was obtained by averaging the following four fingerprints, without weighing since dominant species vary in time: the mean fingerprints obtained for M. viridis, C. raciborskii(Lake Pampulha), Arthrospira sp., and the in situ fingerprint obtained for P. isothrix (on November 21st 2012). Data obtained on October 24th were not included because the phytoplankton biomass was very high on that day (569 $\mu \mathrm{g}$ chl $a \mathrm{~L}^{-1}$ ), beyond the range of linear response of the FP as it will be presented in section 3.2. In order to take into account the uncertainty on the mean experimental cyanobacteria fingerprint due to differences in the fingerprints of the 4 strains, standard deviation at each wavelength was calculated using the four fingerprints described above. The new fingerprint was used to replace that of cyanobacteria stored by default on the FP probe software. By this method, FP was calibrated for cyanobacteria species of Lake Pampulha according to the spectrophotometric method used to quantify chl $a$ in this study. Unfortunately, between the two monitoring periods in 2011 and 2012, the FP was sent to the factory for maintenance and calibration. For this reason, the mean experimental fingerprint could be applied only for measurements carried out in 2012 .

\section{Results and discussion}

\subsection{Phytoplankton abundance in Lake Pampulha}

For the two monitoring periods, chl $a$ concentration measured by spectrophotometry ranged from 42 to $626 \mu \mathrm{g} \mathrm{L}^{-1}$ (mean $=253 \mu \mathrm{g} \mathrm{L}^{-1}$ ). Biovolume ranged between 6 and $148 \mathrm{~mm}^{3} \mathrm{~L}^{-1}$. Over 70 different taxa were identified to the species or genus level by microscopy analysis: 14 for Cyanobacteria, 41 for Chlorophyta, 7 for Euglenophyta, 5 for Cryptophyta and 5 for Bacillariophyta. Phytoplankton and cyanobacteria community composition at sampling point 2, in the middle of the reservoir, are shown in Fig. 2. FP measurements are shown in Fig. 3a 
and $b$, where error bars represent the uncertainty due the standard deviation of relative fluorescence in the experimental cyanobacteria fingerprint.

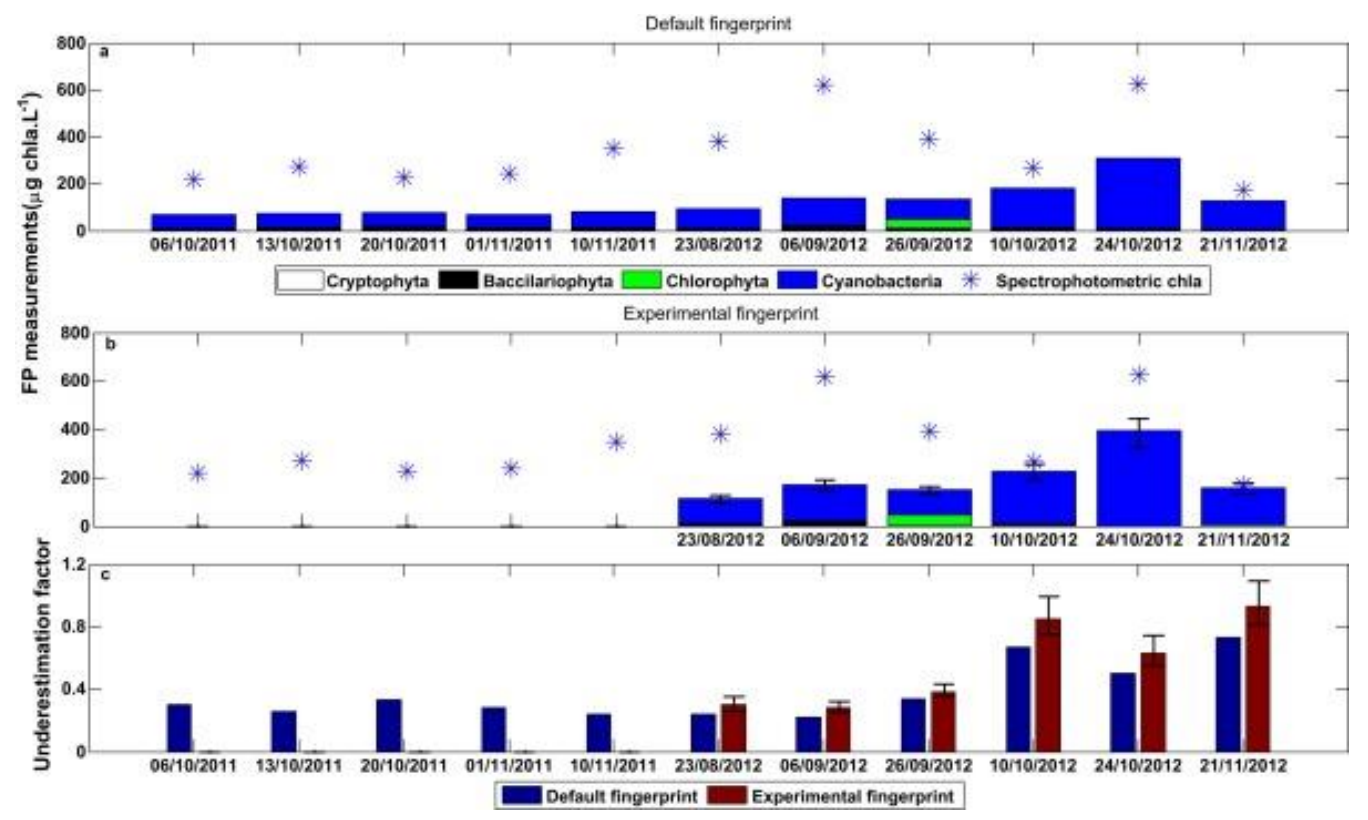

Fig. 3. FP measurements in Lake Pampulha at sampling point 2 (a) using default fingerprint for cyanobacteria and (b) using the experimental fingerprint for cyanobacteria in measurements carried out in 2012 (c) underestimation factor of phytoplankton biomass by the FP compared to spectrophotometry, using default and experimental fingerprints for cyanobacteria. Error bars represent uncertainty on cyanobacteria biomass due to variation in the experimental cyanobacteria fingerprint.

All samples collected in 2011 were highly dominated by cyanobacteria species (at least $85 \%$ of the phytoplankton total biomass). Within the cyanobacteria, the most abundant species were the Oscillatoriales Planktothrix isothrix, the Nostocales Cylindrospermosis raciborskii, and the Chroococcales Sphaerocavum brasiliense, the former two corresponding together to at least $50 \%$ of the cyanobacteria biomass. Between late August and early September 2012, the Euglenophyta Trachelomonas volvocinopsis showed a quite remarkable increase that was likely associated with an input of organic matter in the reservoir, indicated by an increase in the relative concentrations of CDOM measured by FP. Euglenophyta are frequently found in water bodies with high concentration of organic matter (e.g.Solórzano et al., 2011). From late September until late November 2012, cyanobacteria were dominant again, especially $P$. isothrix (Fig. 2).

\subsection{Chlorophyll concentration range for the linear response of the FP}

Laboratory dilution experiments allowed us to determine the range of linear response of the FP. FP measurements (using default fingerprint) and spectrophotometric chl $a$ are plotted in Fig. 4 against the expected chl $a$, ratio between raw sample chl $a$ measured by spectrophotometry and the dilution factor. FP and spectrophotometric measurements were highly correlated $(r=0.97$, 
$\left.p=10^{-6}, n=11\right)$, but the FP probe response was no longer linear above around $100 \mu \mathrm{g}$ chl $a \mathrm{~L}^{-1}$ (measurements on 06/09/2012), while spectrophotometry provided a linear response over the whole concentration range. The more concentrated the sample, the more FP underestimates the phytoplankton total biomass compared to spectrophotometry. For instance, on September 6th the ratio between FP measurement and spectrophotometric chlavaried between 0.52 (dilution factor $=8)$ and 0.25 (dilution factor $=1)$.

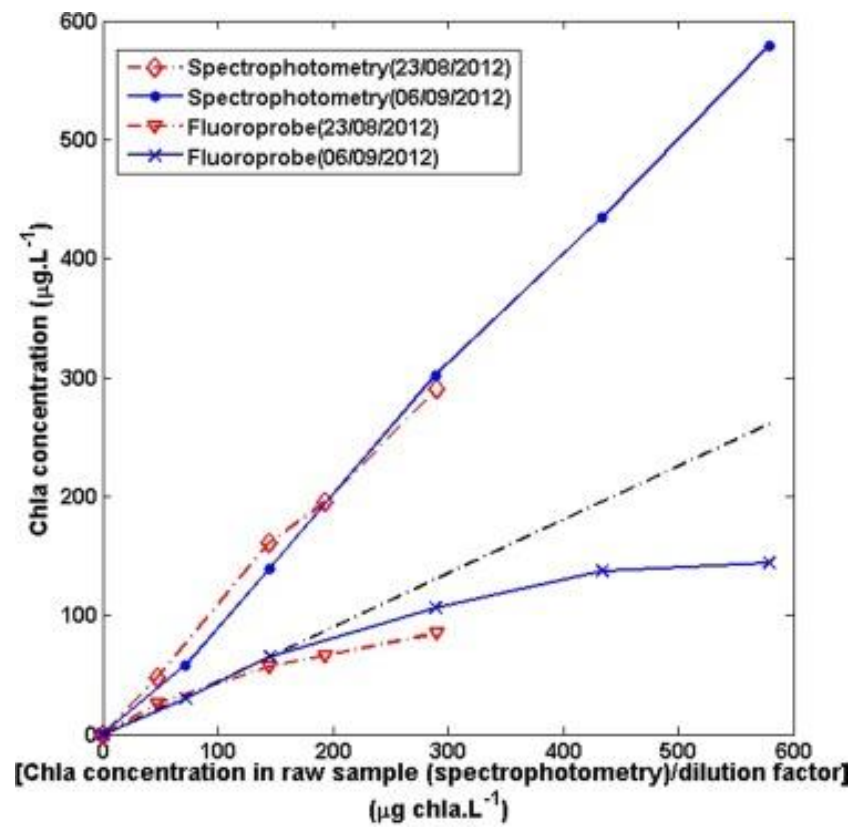

Fig. 4. Range of linear response of FP from dilution experiments on water samples from Lake Pampulha collected on 23rd August and 06th September 2012. The slope of the line is the mean ratio between FP and spectrophotometric chl $a$ for spectrophotometric chlabelow $150 \mu \mathrm{g} \mathrm{L}^{-1}$.

The non-linear response observed for the probe suggests that above a threshold of phytoplankton biomass, the sample is no longer optically thin. The light emitted by the diodes and the fluorescence emitted by phytoplankton cells are then shaded, scattered and re-absorbed, leading to a non-linear response of the probe and an underestimation of the phytoplankton biomass (Gregor and Maršálek, 2004).

Optical density is determined by suspended solids concentration and phytoplankton biomass. Therefore, the upper limit of chla concentration range for reliable FP measurement may change according to the phytoplankton community assemblage and suspended solids concentration. In six water bodies in Czech Republic, Gregor et al. (2004) found an upper limit of $50 \mu \mathrm{g} \operatorname{chl} a \mathrm{~L}^{-1}$, whereas under laboratory conditions, Beutler et al. (2002) found linearity up to $400 \mu \mathrm{g} \operatorname{chl} a \mathrm{~L}^{-1}$. The threshold we measured, around $100 \mu \mathrm{g} \operatorname{chl} a \mathrm{~L}^{-1}$, is in between.

3.3. Comparisons between FP and spectrophotometric measurements and phytoplankton biovolume 
In order to verify FP performance we compared its measurements with the results of other "traditional" methods used for phytoplankton quantification. We carried out a cross comparison between FP and spectrophotometric measurements and phytoplankton total and taxonomic group biovolume. To avoid bias, extreme samples where spectrophotometric chl $a$ exceeded 500 $\mu \mathrm{g} \mathrm{L} \mathrm{L}^{-1}$ and those where biovolume was above $148 \mathrm{~mm}^{3} \cdot \mathrm{L}^{-1}$, were not included in the correlation analysis.

Spectrophotometric results and FP measurements for total phytoplankton (with default fingerprint, Fig. 5a) were weakly correlated $(r=0.43, p=0.01, n=35)$. When FP measurements were separated in two groups, higher and lower than $100 \mu \mathrm{g} \operatorname{chl} a \mathrm{~L}^{-1}$, in an attempt to reduce the effects of non-linearity on the probe response, the correlation was highly significant below 100 chla $\mathrm{L}^{-1}(r=0.84, p<0.001, n=25)$ and insignificant above $(r=0.17$, $p=0.63, n=10$ ). However, even if we consider only FP measurements below $100 \operatorname{chl} a \mathrm{~L}^{-1}$ the correlation with spectrophotometric chl $a$ is lower than those reported in the literature $(r=0.97$ in Catherine et al., 2012; $r=0.95$ in Gregor et al., 2005; $r=0.96$ in Izydorczyk et al., 2009).
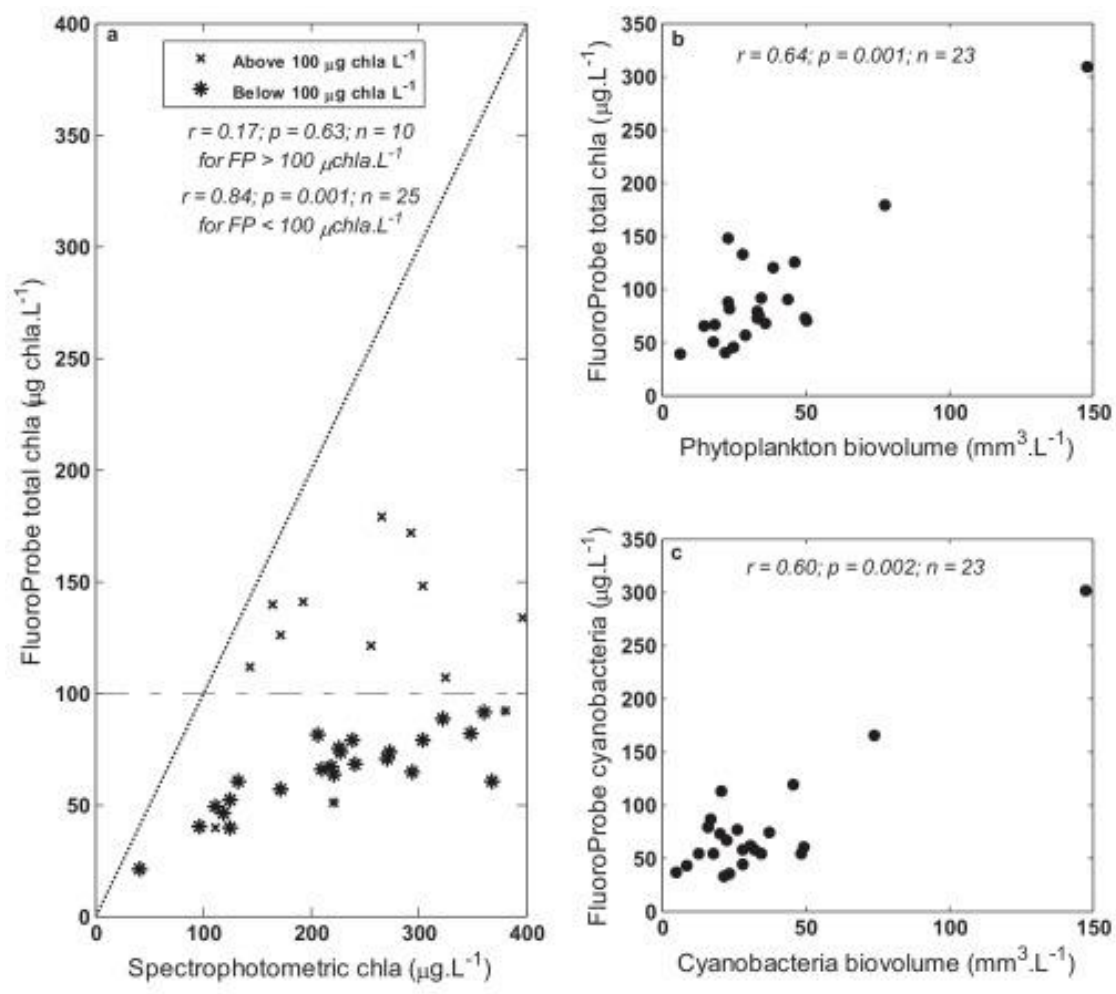

Fig. 5. FP, spectrophotometric analyses and phytoplankton biovolume measurements in Lake Pampulha. In (a): dotted line represents 1:1 slope and dashed line represents $100 \mu \mathrm{g}$ chl $a \mathrm{~L}^{-1}$ measured by the FP.

Total phytoplankton biovolume was compared to FP chla measurements (with default fingerprint, Fig. 5b) and spectrophotometric analysis. Cyanobacteria biovolume and FP measurements of the cyanobacteria group were also compared (Fig. 5c). The total phytoplankton biovolume was significantly correlated to chl $a$ concentration measured by FP ( $r$ 
$=0.64, p=0.001, n=23)$. Cyanobacteria biovolume was also significantly correlated to the cyanobacteria estimated by the probe $(r=0.60, p=0.002, n=23)$. These results obtained using FP default fingerprints, i.e. no site-specific calibration, show that FP was able to provide a quite good assessment of phytoplankton total biomass and biomass of the dominant group in Lake Pampulha. Nevertheless, the correlations remained weaker than reported in the literature, for FP measurements and phytoplankton biovolume ( $r=0.89$ in Catherine et al., 2012), as well as for FP cyanobacteria measurements and cyanobacteria biovolume ( $r=0.79$ in Catherine et al., $\underline{2012}$ and $r=0.68$ in Izydorczyk et al., 2009). We attribute these weaker correlations to the non-linear response of the probe at high phytoplankton biomass.

Total phytoplankton biovolume and spectrophotometric chl $a$ showed no significant correlation ( $r=0.37, p=0.08, n=23$ ), which raises the issue whether spectrophotometric measurements are representative of phytoplankton biomass in Lake Pampulha. No significant correlations were found for diatoms biovolume and FP measurements ( $r=0.40, p=0.06, n=23$ ) and Chlorophyta biovolume and FP measurements ( $r=0.33, p=0.12, n=23)$. In Lake Pampulha, the biomass of non-dominant phytoplankton groups could thus not be properly measured using the FP.

\subsubsection{Underestimation factor}

The ratio between FP (with default fingerprint) and spectrophotometric measurements, called hereafter "underestimation factor", was calculated for each sample and compared to other studies in Table 2. Underestimation factor is also shown in Fig. 3c for data from sampling point 2. On average, this factor presented a value of $0.36( \pm 0.20)$. This underestimation is likely due to the supplier's calibration of the FP by $\underline{\text { HPLC}}$, which is known for providing lower values of chla concentration than spectrophotometry (Meyns et al., 1994). Allomers and chl $a$ derivates are detected together by spectrophotometry at $685 \mathrm{~nm}$, but they are separated chromatographically during HPLC analysis. 
Table 2. FluoroProbe underestimation factors reported in scientific literature.

\begin{tabular}{|c|c|c|c|c|}
\hline $\begin{array}{l}\text { Extraction } \\
\text { solvent }\end{array}$ & $\begin{array}{l}\text { Spectrophotometric } \\
\text { chlaconcentration range }\end{array}$ & $\begin{array}{l}\text { No. of } \\
\text { monitored } \\
\text { sites }\end{array}$ & $\begin{array}{l}\text { aUnderestimation } \\
\text { factor }\end{array}$ & Reference \\
\hline Acetone & $0-20 \mu \mathrm{g} \mathrm{L}^{-1}$ & 1 & a 1.03 & $\begin{array}{l}\text { Leboulanger et } \\
\underline{\text { al. }(2002)}\end{array}$ \\
\hline Ethanol & $0-50 \mu \mathrm{g} \mathrm{L}^{-1}$ & 6 & a 0.83 & $\frac{\text { Gregor and }}{\text { Maršálek (2004) }}$ \\
\hline Ethanol & $0-90 \mu \mathrm{g} \mathrm{L}^{-1}$ & 5 & a 0.74 & $\begin{array}{ll}\text { Gregor et al. } \\
\underline{(2005)}\end{array}$ \\
\hline Methanol & $0-265 \mu \mathrm{g} \mathrm{L}^{-1}$ & 50 & ㄴ 0.56 & $\begin{array}{l}\text { Catherine et al. } \\
\underline{(2012)}\end{array}$ \\
\hline Ethanol & $42-626 \mu \mathrm{g} \mathrm{L}^{-1}$ & 1 & a 0.36 and $\mathrm{b} 0.27$ & Present work \\
\hline
\end{tabular}

a

Underestimation factors were computed through linear regression $\mathrm{y}=a \mathrm{x}$, where $y$ is chlaconcentration provided by FP, $x$ is the spectrophotometric chl $a$ concentration and $a$ is the underestimation factor.

$\mathrm{b}$

The underestimation factor is a mean ratio between FP and spectrophotometric measurements.

One could note that the underestimation varies between different studies (Table 2). Multiple causes may explain these variations, for instance, the organic solvents used to extract chla during spectrophotometric analysis present different extraction efficiencies (Nusch, 1980; Talling 1993), different development stages of phytoplankton and nutrient limitations that may also contribute to variations in the pigment content of the cells (Beutler et al., 2002). According to MacIntyre et al. (2010), to compensate nutrient limitation at the peak moment, cyanobacteria may change their photosynthetic apparatus and increase fluorescence emission. Thus, during cyanobacteria peak growth stages, differences between FP and spectrophotometric chla concentration may be smaller (Gregor et al., 2005).

We tested this hypothesis by computing correlation between underestimation factor and phytoplankton total biovolume. The lack of correlation between the underestimation factor and total phytoplankton biovolume $(r=-0.203, p=0.35, n=23)$ did not allow us to confirm the hypothesis in Lake Pampulha, where cyanobacteria peaks represent extremely high densities of cells. However, the underestimation factor varied with the dominant species in the sample. When Chroococcales species represented more than $20 \%$ of the cyanobacteria biovolume (or Oscillatoriales represented less than $40 \%$ of the cyanobacteria biovolume), the FP further underestimated chl $a$ concentration (underestimation factor $<0.34, p=0.003$, Fig. $3 \mathrm{c}$ and Fig. 6). Chroococcales species may form large colonies during blooms, which can disrupt the probe operation due to light reabsorption and dispersion effects. In addition, larger colonies do not allow the penetration of light and inner cells are not excited (Augusti and Phlips, 1992; Gregor 
and Maršálek, 2004). When Oscillatoriales species, such as $P$. isothrix, represented more than $50 \%$ of the cyanobacteria biovolume, there was less underestimation (underestimation factor close to 1, Fig. $3 \mathrm{c}$ and Fig. 6 ).

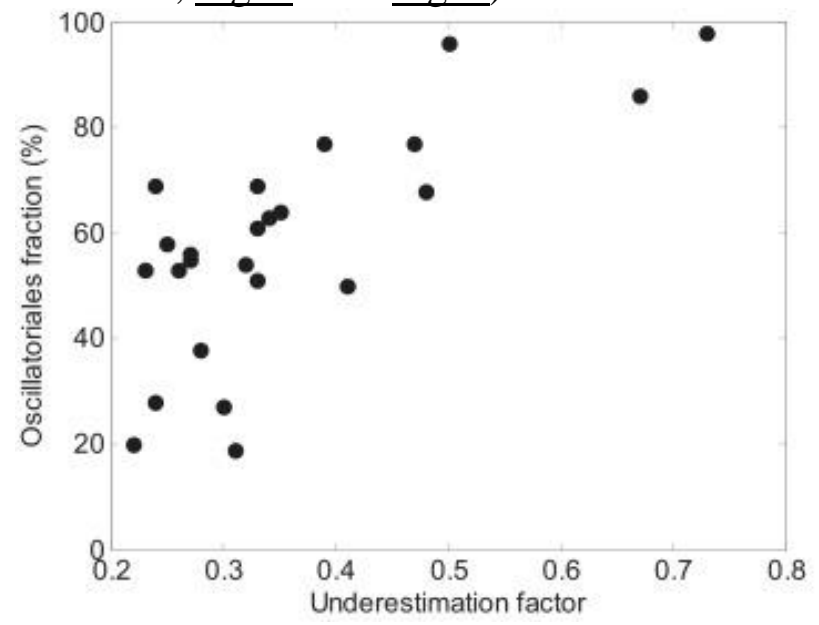

Fig. 6. Oscillatoriales fraction and underestimation factor (dots below $40 \%$ of Oscillatoriales fraction correspond to Chroococcales dominance).

\subsection{Experimental cyanobacteria fingerprints in Lake Pampulha}

The experimentally calculated fingerprints are presented in Table 3 and in Fig. 7. The fingerprints experimentally obtained from cyanobacteria cultures and field samples for $P$. isothrix were close to the default excitation spectrum for cyanobacteria supplied by the FP software. This validates one of the prerequisites for the probe operation: the fingerprint shape of a taxonomic group should be constant and independent of the physiological state, cell density and strains used (Beutler et al., 2002). However, the Oscillatoriales P. isothrix and Arthrospira sp. presented less fluorescence per chl $a$ unit at $590 \mathrm{~nm}$ and $610 \mathrm{~nm}$ than the Chroococcales $M$. viridis and the Nostocales $C$. raciborskii whose fingerprints were very similar. Applying the default cyanobacteria fingerprint in a sample dominated by Oscillatoriales will lead to an overestimation of their biomass, which probably contributed to a smaller FP underestimation compared to spectrophotometric measurements when Oscillatoriales were the dominant species, as described seen in section 3.3.1. Although, variability on the relative fluorescence of the Oscillatoriales group is not expected to cause inaccuracies in the taxonomic classification, because peaks at $610 \mathrm{~nm}$ are not so pronounced in the fingerprints of other phytoplankton groups as found in cyanobacteria fingerprint. 
Table 3. Lake Pampulha cyanobacteria fingerprints [relative fluorescence (units $\mu \mathrm{g}^{-1} \mathrm{chl} \mathrm{a} \mathrm{L}^{-1}$ )].

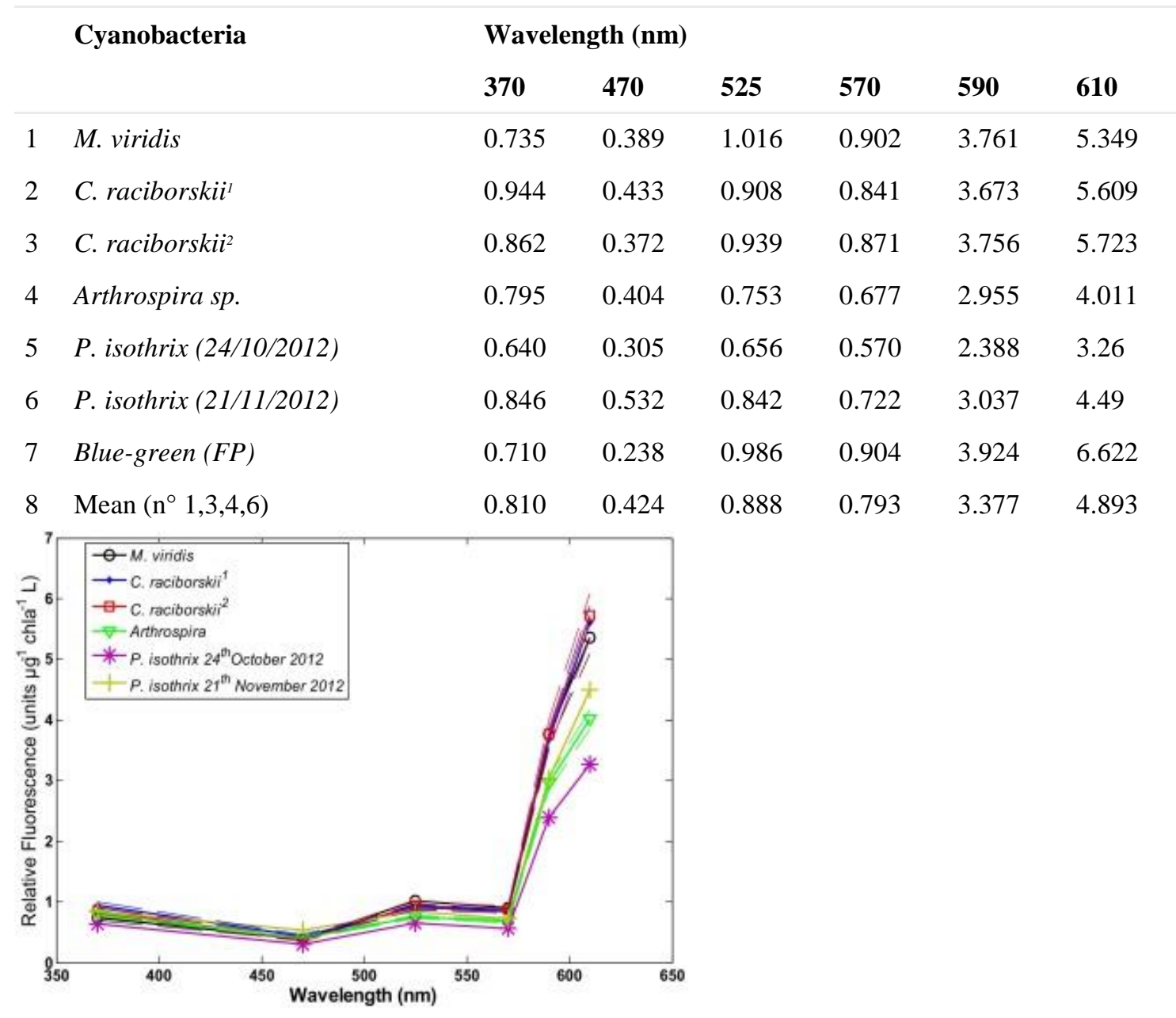

Fig. 7. Cyanobacteria fingerprints of the dominant species found in Lake Pampulha. Continuous lines represent mean fingerprint value. Dotted lines represent mean fingerprint value \pm standard deviation $(\mathrm{n}=8)$. ${ }^{\mathrm{C}}$. raciborskii from Lake Pampulha and ${ }^{2}$ C. raciborskiifrom Lagoa Santa reservoir.

The FP manufacturer obtained the default fingerprints from the following laboratory culture mixture for cyanobacteria: Microcystis aeruginosa (6 strains), Microcystis wesenbergii (8 strains), Microcystis viridis, Anabaena sp., Aphanizomenon sp. and Synechococcus leopoliensis (Beutler et al., 2002). Additionnally to the default fingerprints, Leboulanger et al. (2002) implemented a new fingerprint to take into account the phycoerythrin-rich cyanobacterium $P$. rubescens. Houliez et al. (2012) also recorded a new fingerprint for monitoring the cyanobacterium Phaeocystis globosa in the coastal waters of the eastern English Channel. However, as far as we are aware, Oscillatoriales cultures have not yet been used to calibrate FP fingerprints.

Non linearity of the fluorescence to biomass, as discussed on section 3.2, is also observed in fingerprints. The relative fluorescence of $P$. isothrix at $610 \mathrm{~nm}$ was almost $40 \%$ lower at 569 $\mu \mathrm{g} \operatorname{chl} a \mathrm{~L}^{-1}(24 / 12 / 2012)$ than at $153 \mu \mathrm{g} \operatorname{chl} a \mathrm{~L}^{-1}(21 / 11 / 2012)$ (Fig. 7). 
The mean experimental fingerprint obtained for cyanobacteria in Lake Pampulha is shown in Fig. 8, where dotted lines represent standard deviation. It is closer to P. isothrix and Arthrospira sp. fingerprints than the FP default fingerprint. When using the mean experimental fingerprint (Fig. 3), chlaconcentrations measured by FP increased, as well as cyanobacteria contribution to the phytoplankton total biomass (see Fig. 3). The experimental fingerprint could be applied only on measurements carried out on $2012(\mathrm{n}=10)$ and these were too few data to obtain an improvement in the correlations between FP measurements and phytoplankton and cyanobacteria biovolume. Nevertheless, applying the experimental fingerprint allowed us to reduce differences between spectrophotometric measurements and FP measurements for total phytoplankton, especially on measurements carried out on October and November 2012 (Fig. $\underline{3 c}$ ) when a single species, P. isothrix, was highly dominant. We hypothesize that the improvement on FP performance on August and September 2012 was smaller due to the variety of cyanobacteria species, including Chroococcales and Oscillatoriales. However, applying experimental monospecific $M$. viridis or $C$. raciborskii finperprints at these dates did not provide better results (data not shown) than the experimental (mean) fingerprint.

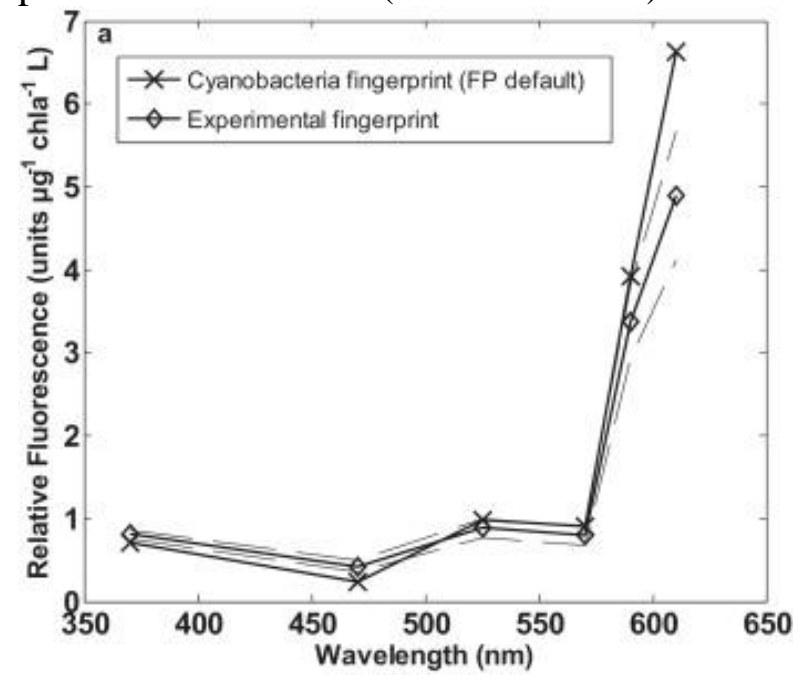

Fig. 8. FP default fingerprint for "cyanobacteria" and fingerprint calculated for cyanobacteria species of Lake Pampulha. Dotted lines represent standard deviations in units $\mu \mathrm{g}^{-1} \mathrm{chla}^{-1} \mathrm{~L}: 0.066$ $(370 \mathrm{~nm}) ; 0.036(470 \mathrm{~nm}) ; 0.119(525 \mathrm{~nm}) ; 0.108$ (570 nm); $0.424(590 \mathrm{~nm}) ; 0.786(\mathrm{~nm})$.

\subsection{Biovolume/chla ratio}

Catherine et al. (2012) proposed to correct total chla measured by the FP for each taxonomic group by using a mean ratio of chla content per unit of biovolume in each group. This ratio was calculated from data presented by Reynolds (2006) for Cyanobacteria $\left(0.18 \mathrm{~mm}^{3} \mu \mathrm{g} \mathrm{chl} a^{-1}\right)$, Chlorophyta $\left(0.09 \mathrm{~mm}^{3} \mu \mathrm{g} \operatorname{chl} a^{-1}\right)$ and Bacillariophyta $\left(0.39 \mathrm{~mm}^{3} \mu \mathrm{g} \operatorname{chl} a^{-1}\right)$ and multiplied by FP measurements. This procedure improved the correlation between phytoplankton total biovolume and FP total chla $(r=0.70, p<0.001, n=23)$. The ratio chla per unit of biomass is not constant between phytoplankton species, as already stated by some authors (Desortova, 1981; Kasprzak et al., 2008; Reynolds, 2006; Talling, 1993), although contested by others (Vörös and Padisák, 1991). Our data showed that within cyanobacteria group, chla/biovolume 
ratio may be quite variable, with average at standard deviation $6.5 \pm 3.4 \mu \mathrm{g} \mathrm{chl} a \mathrm{~mm}^{-3}$. This may explain the poor correlation between chlameasured by spectrophotometry and phytoplankton biovolume.

\subsection{Management implications of the FP use in tropical hypereutrophic reservoirs}

In tropical hypereutrophic reservoirs, the high phytoplankton biomass and the high concentrations of suspended solids promote high optical density that leads to a non-linear response of the FP. Therefore, phytoplankton biomass may be severely underestimated during blooms, which is a serious limitation to the use of spectrofluorometer probes such as FP for management purposes. In the case of cyanobacteria, the degree of underestimation may vary according to the species present in the lake, which makes it necessary to perform to microscopy analysis for their identification and then attempt to correct the underestimation.

In the case of cyanobacteria dominance, regardless of species, no misidentification with other phytoplankton groups is expected, since fingerprints obtained here for different cyanobacteria species have similar shapes and differ substantially from the default fingerprints for other phytoplankton groups. This is a very positive aspect for managers of tropical eutrophic lakes that are mostly concerned with the dominance of harmful cyanobacteria. On the other hand, it is worth noting that the noise of the spectra of the groups at high concentration disturbs the determination of less abundant groups (Beutler et al., 2002) and for this reason, FP measurements for Chlorophyta and Baccilariophyta were highly uncertain in this work. Houliez et al. (2012), for example, verified this same effect in samples in which Phaeocystis globosa (Prymnesiophyta) biomass exceeded 55\% of the total algal biomass.

One final note regarding the management implications of the use of FP in reservoirs, such as Lake Pampulha, concerns its more accurate measurements relative to spectrophotometric analysis when compared to phytoplankton total biovolume. Catherine et al. (2012) who found similar results argue that in vivofluorescence may integrate some degree of variability regarding the functioning of the phytoplankton photosynthetic apparatus.

\section{Conclusions}

We investigated the conditions of use of an in situ spectrofluorometer in the tropical Lake Pampulha. Our results indicated that in a hypereutrophic reservoir the use of spectrofluorometers such as FP deserves some caution, because high optical density, due to very high algal biomass, leads to a non-linear response of the probe and brings uncertainties that may be even larger than those resulting from the non-calibration of the probe for a given site. These uncertainties are reflected in the underestimation of the phytoplankton biomass, which implies that, during algal blooms, when the knowledge of phytoplankton abundance is important for both research and management purposes, the probe may lead to inaccurate estimation. 
The non-linearity observed in the spectrofluorometer response above a chlaconcentration of $100 \mu \mathrm{g} . \mathrm{L}^{-1}$ depends on the site, as well on the species of cyanobacteria, which prevents the use of a simple correction factor for FP measurements. Chroococcales species may present colonial morphology that prevents the probe from exciting cells inside the colony, leading to the underestimation of their biomass by FP. When Oscillatoriales species are dominant, specific fingerprint calibration is needed to properly assess their biomass.

We concluded that particularly in case of highly eutrophic tropical reservoirs, simultaneous laboratory analyses are still necessary to corroborate the probe measurements, more than in oligotrophic or mesotrophic water bodies. Nevertheless, in situ spectrofluorometers are easyto-handle devices and their use may provide a suitable spatial and temporal resolution of phytoplankton abundance and diversity in optimal situations. These attributes may be very useful for water quality monitoring purposes, as for instance in drinking water reservoirs or recreational water bodies. For these reasons, further studies are necessary to improve the performance of spectrofluorometers, especially in tropical, highly eutrophic lakes and reservoirs.

\section{Acknowledgements}

We would like to thank both reviewers for the careful reading and helpful suggestions. This work was part of the MAPLU 2 project funded by the Brazilian agency FINEP (Financiadora de Estudos e Projetos). A. Giani and N. Nascimento are CNPq fellows (researcher fellowship program). We thank CAPES and Ecole des Ponts Paris Tech for the PhD scholarship to the first author; LEESU (Laboratoire Eau, Environnement et Systèmes Urbains) for lending the bbe FluroProbe and the Belo Horizonte Municipality for its collaboration. Thanks to the CAPESCOFECUB (Coordenação de Aperfeiçoamento de Pessoal de Nível Superior-Comité Français d'Évaluation de la Coopération Universitaire et Scientifique avec le Brésil) project, the exchange of researchers was made possible. We are also grateful to Jean-François Humbert, Philippe Dubois, Mohamed Saad, Martin Seidl, Daniel Zuim and Elenice Silva for their support in different moments of this research.

\section{References}

S. Augusti, E.J. Phlips Light absorption by cyanobacteria: implications of the colonial growth form Limnol. Oceanogr., 37 (1992), pp. 434-441

M. Beutler, K.H. Wiltshire, B. Meyer, C. Moldaenke, C. Lüring, M. Meyerhöfer, U.P. Hansen, H. Dau A fluorometric method for the differentiation of algal populations in vivo and in situ Photosynth. Res., 72 (2002), pp. 39-53 
M. Bouvy, R. Molica, S. Oliveira, M. Marinho, B. Beker Dynamics of a toxic cyanobacterial bloom (Cylindrospermopsis raciborskii) in a shallow reservoir in the semi-arid region of northeastBrazil Aquat. Microb. Ecol., 20 (1999), pp. 285-297

M. Bouvy, S.M. Nascimento, R.J.R. Molica, A. Ferreira, V. Huszar, S.M.F.O.Azevedo Limnological features in Tapacurá reservoir (northeast Brazil) during a severe drought

Hydrobiologia, 493 (2003), pp. 115-130

E. Carraro, N. Guyennon, D. Hamilton, L. Valsecchi, E.C. Manfredi, G.Viviano, F. Salerno, G. Tartari, D. Copetti Coupling high-resolution measurements to a three-dimensional lake model to assess the spatial and temporal dynamics of the cyanobacterium Planktothrixrubescens in a medium-sized lake

Hydrobiologia, 698 (2012), pp. 77-95

A. Catherine, N. Escoffier, A. Belhocine, A.B. Nasri, S. Hamlaoui, C.Yéprémian, C. Bernard, M. Troussellier On the use of the FluoroProbe ${ }^{\circledR}$, a phytoplankton quantification method based on fluorescence excitation spectra for large-scale surveys of lakes and reservoirs

Water Res., 46 (6) (2012), pp. 1771-1784

H. Dau Chlorophyll fluorescence measurements for assessment of primary production in aquatic ecosystems-the basics

Rostck. Meeresbiol. Beitr, 6 (1998), pp. 23-40

B. Desortova Relationship between chlorophyll-a concentration and phytoplankton biomass in several reservoirs in Czechoslovakia

HInt. Rev. Ges. Hydrobiol., 66 (1981), pp. 153-169

T. Dworak, C. Gonzalez, C. Laaser, E. Interwies The need for new monitoring tools to implement the WFD

Environ. Sci. Policy, 8 (2005), pp. 301-306

J. Gregor, B. Maršálek Freshwater phytoplankton quantification by chlorophyll a: a comparative study of in vitro, in vivo and in situ methods

Water Res., 38 (3) (2004), pp. 517-522

J. Gregor, R. Geriš, B. Maršálek, J. Heteša, P. Marvan In situ quantification of phytoplankton in reservoirs using a submersible spectrofluorometer

Hydrobiologia, 548 (2005), pp. 141-151 
E. Houliez, F. Lizon, M. Thyssen, L.F. Artigas, F.G. Schmitt Spectral fluorometric characterization of Haptophyte dynamics using the FluoroProbe: an application in the eastern english channel for monitoring Phaeocystisglobosa

J. Plankton Res., 34 (2) (2012), pp. 136-151

E. Houliez, F. Lizon, L.F. Artigas, F.G. Schmitt Phytoplankton photosynthetic activity dynamics in a temperate macrotidal ecosystem (the Strait of Dover, eastern English Channel): time scales of variability and environmental control

Mar. Syst., 147 (2015), pp. 61-75

Huot, Y., Babin, M., 2010. Overview of Fluorescence Protocols: theory, basic concepts, and practice. In: Sugget, D.J. et al. (eds.), Chlorophyll a Fluorescence in Aquatic Sciences: Methods and Application. Developments in Applied Phycology, 4, p. $31-74$.

K. Izydorczyk, C. Carpentier, J. Mrówczyński, A. Wagenvoort, T. Jurczak, M. Tarczyńska Establishement of an alert level framework for cyanobacteria in drinking water ressources by using the algae online analyser for monitoring cyanobacterial chlorophylla

Water Res., 43 (2009), pp. 989-996

Jeffrey et al., 1997 Phytoplankton Pigments in Oceanography: Guidelines to Modern Methods

S.W. Jeffrey, R.F.C. Mantoura, S.W. Wright (Eds.), Unesco, Paris (1997)

$661 \mathrm{p}$

P. Kasprzak, J. Padisak, R. Koschel, L. Krienitz, F. Gervais Chlorophyll a concentration across a trophic gradient of lakes: an estimator of phytoplankton biomass?

Limnol. Ecol. Manag. Inland Waters, 38 (3-4) (2008), pp. 327-338

C. Lafabrie, M. Garrido, C. Leboulanger, P. Cecchi, G. Grégori, V.Pasqualini, O. Pringault Impact of contamined-sediment resuspension on phytoplankton in the Biguglia lagoon (Corsica, Mediterranean Sea)

Estuar. Coast. Shelf Sci., 130 (2013), pp. 70-80

C. Leboulanger, U. Dorigo, S.P. Jacquet, B. Le Berre, G.R. Paolini, J.-F.O. Humbert Application of a submersible spectrofluorometer for rapid monitoring of freshwater cyanobacterial blooms: a case study

Aquat. Microb. Ecol., 30 (2002), pp. 83-89

W.M. Lewis Jr. Tropical lakes: how latitude makes a difference

F. Schiemer, K.T. Boland (Eds.), Perspectives in Tropical Limnology, SPB Academic Publishers, Amsterdam, the Netherlands (1996), pp. 43-64

W.M. Lewis Jr. Basis for the protection and management of tropical lakes

Lakes Reservoirs: Res. Manag., 5 (2000), pp. 35-48 
MacIntyre, H.L., Lawrenz, E., Richardson, T.L., 201.Taxonomic discrimination of phytoplankton by spectral fluorescence. In: Suggett, D.J. et al. (Eds.), Chlorophyll a Fluorescence in Aquatic Sciences: Methods and Applications. Developments in Applied Phycology, 4, p. 129-169.

D.A. Machado, C.L. Marti, J. Imberger Influence of microscale turbulence on the phytoplankton of a temperate coastal embayment, Western Australia

Estuar. Coast. Shelf Sci., 145 (2014), pp. 80-95

C.L. Marti, R. Mills, J. Imberger Pathways of multiple inflows into a stratified reservoir: Thomson Reservoir, Australia

Adv. Water Resour., 34 (2011), pp. 551-561

S. Meyns, R. Illi, B. Ribi Comparison of chlorophyll-a analysis by HPLC and spectrophotometry: Where do the differences come from?

Archives für Hydrobiologie, 132 (1994), pp. 129-139

E.A. Nusch Comparison of different methods for chlorophyll and phaeopigmentdetermination Arch. Hydrobiol. Beih., 14 (1980), pp. 14-36

R. Paxinos, J.G. Mitchell A rapid Uthërmol method for estimating algal numbers

J. Plankton Res., 22 (12) (2000), pp. 2255-2262

R.P. Resck, J.F. Bezerra Neto, R.M.C. Mota Coellho Nova batimetria e avaliação de parâmetros morfométricos da lagoa da Pampulha (Belo Horizonte, Brasil)

Geografias Artigos Científicos, 3 (2) (2007), pp. 24-37

C.S. Reynolds The Ecology of Phytoplankton

Cambridge University Press, Cambridge, UK (2006)

$535 \mathrm{p}$

A.J. Richardson In hot water: zooplankton and climate change

ICES J. Mar. Sci., 65 (2008), pp. 279-295

A. Rolland, F. Rimet, S. Jacquet A 2-year survey of phytoplankton in the Marne Reservoir (France): a case study to validate the use of an in situ spectrofluorometer by comparison with algal taxonomy and chlorophyll a measurements

Knowledge Manag. Aquat. Ecosyst., 398 (2010)

02p01-02p19

E. Rott Some results from phytoplankton counting intercalibrations

Schweiz. Z. Hydrol., 43 (1981), pp. 34-62 
M. Søndergaard, E. Jeppesen, T.L. Lauridsen, C. Skov, E.H. Van Nes, R. Roijackers, E. Lammens, R. Portielje Lake restoration: successes, failures and long-term effects

J. Appl. Ecol., 44 (2007), pp. 1095-1105

N. Salmaso, D. Copetti, L. Cesarino, S. Shams, C. Capelli, A. Boscaini, L.Valsecchi, F. Pozzoni, L. Guzzella Variability of microcystin cell quota in metapopulations of Planktothrixrubescens: causes and implications for water management

Toxicon, 90 (2014), pp. 82-96

G.G. Solórzano, M.G.O. Martinez, A.L. Vazquez, M.B.M. Garfias, R.E.Q.Zuniga, V. Conforti Trachelomonas (Euglenophyta) from a eutrophic reservoir in Central Mexico

J. Environ. Biol., 32 (2011), pp. 463-471

J.F. Talling Comparative seasonal changes, and inter-annual variability and stability, in a 26-year record of total phytoplankton biomass in four English lake basins

Hydrobiologia, 268 (1993), pp. 65-98

H. Utermöhl ZurVervollkmnung der quantitativen phytoplankton-methodik

Mitt. Int. Verh. Theor. Angew. Limnol., 9 (1958), pp. 165-174

E. von Sperling The process of biomass formation as the key point in the restoration of tropical eutrophic lakes

Hydrobiologia, 342-343 (1997), pp. 351-354

L. Vörös, J. Padisák Phytoplankton biomass and chlorophyll-a in some shallow lakes in central Europe

Hydrobiologia, 215 (1991), pp. 111-119 